\title{
Indigofera wenholdiae (Indigofereae, Fabaceae), a new species from the Western Cape Province, South Africa
}

\author{
Brian du Preez ${ }^{1,2}$, Leanne L. Dreyer ${ }^{2}$, Charles H. Stirton', \\ A. Muthama Muasya', Brian D. Schrire ${ }^{3}$
}

I Bolus Herbarium, Department of Biological Sciences, University of Cape Town, Private Bag X3, Rondebosch, 7701, South Africa 2 Department of Botany and Zoology, Stellenbosch University, Private Bag X1, Matieland, 7602, South Africa 3 Comparative Plant and Fungal Biology Department, Royal Botanic Gardens, Kew, Richmond, Surrey, TW9 3AE, UK

Corresponding author: Brian du Preez (brian.enviro@gmail.com)

Academic editor: Patrick Herendeen | Received 26 July 2021 | Accepted 20 August 2021 | Published 1 October 2021

Citation: du Preez B, Dreyer LL, Stirton CH, Muasya AM, Schrire BD (2021) Indigofera wenholdiae (Indigofereae, Fabaceae), a new species from the Western Cape Province, South Africa. PhytoKeys 182: 107-112. https://doi. org/10.3897/phytokeys.182.72170

\begin{abstract}
In this study, Indigofera wenholdiae, a new species of Fabaceae from the Agulhas Plain Region of the Western Cape Province, South Africa, is described. A composite photographic plate is included along with a distribution map, description of habitat and ecology and proposed IUCN conservation status. Indigofera wenholdiae is unique in the I. brachystachya group by having digitately compound (vs. pinnately compound) leaves, white and unscented flowers (vs. pink and sweetly scented flowers) and grows on sandstone hillsides (vs. coastal limestone plains and outcrops).
\end{abstract}

\section{Keywords}

Indigofera, Leguminosae, Greater Cape Floristic Region, fynbos, taxonomy

\section{Introduction}

Fabaceae represents the second largest plant family in the Cape Floristic Core Cape Region (CCR), approaching 800 species (Manning and Goldblatt 2012). The genus Indigofera L. with about 90 species in the region, is second only to Aspalathus L.

Copyright Brian du Preez et al. This is an open access article distributed under the terms of the Creative Commons Attribution License (CC BY 4.0), which permits unrestricted use, distribution, and reproduction in any medium, provided the original author and source are credited. 
(270+ species) in size (Dahlgren 1988; Schrire in Manning and Goldblatt 2012). Indigofera species in the CCR are largely part of a monophyletic clade referred to as the Cape Clade by Schrire et al. (2009). Unlike the three main tropical clades that have members dispersed across multiple continents, the Cape Clade is endemic to South Africa and especially within the winter-rainfall area (Schrire et al. 2009; Schrire in Manning and Goldblatt 2012). A large group within the Cape Clade, Section Brachypodae Schrire, is prolific in Fynbos vegetation and has many localised species, often associated with preferences for specific microhabitats. Diverse geological formations, as seen in the Agulhas Plain region (Thwaites and Cowling 1988), have resulted in localised radiations in many plant groups (Cowling and Holmes 1992; Manning and Goldblatt 2012). For example, over 20 new legume species have been recently described from various genera, including Aspalathus L., Otholobium C.H.Stirt., Polhillia C.H.Stirt., Psoralea L. and Rhynchosia Lour. (Curtis et al. 2013; Moteetee et al. 2014; Stirton and Muasya 2016, 2017; Bello et al. 2017; Du Preez et al. 2021). Members of Indigofera Section Brachypodae, particularly the I. brachystachya group (I. brachystachya (DC.) E.Mey. and I. hamulosa Schltr.), are especially diverse in this region, with several putative undescribed taxa related to $I$. brachystachya, noted from recent field studies (Schrire and du Preez, unpublished data). While further, more detailed, analyses are required to resolve this species complex, we here describe a new, distinctive species from the I. brachystachya group first found in the Grootbos Nature Reserve in 2020.

\section{Material and methods}

The description of morphological characters is based on freshly collected material and herbarium voucher specimens. The conservation assessment was done using the Categories and Criteria of the IUCN (2012). The Extent of Occurrence (EOO) and Area of Occurrence (AOO) were calculated using GeoCAT (www.geocat.kew.org). The distribution map was made using QGIS 3.18 software (www.qgis.org).

\section{Species treatment}

\section{Indigofera wenholdiae du Preez \& Schrire, sp. nov.} urn:lsid:ipni.org:names:77220006-1

Diagnosis. Similar to I. brachystachya, but differs in its digitately compound, 5-7 foliolate leaves (versus pinnately compound, 7-9 foliolate leaves), leaflets $4-6 \mathrm{~mm}$ long (versus leaflets 9-15 $\mathrm{mm}$ long), racemes up to $7 \mathrm{~mm}$ long, flowers $\pm 4-5$ per raceme (versus racemes $>10 \mathrm{~mm}$ long, flowers $>8$ per raceme), flowers creamy white, unscented (versus flowers pale pink, scented), branching divaricate (versus branching random), populations restricted to sandstone fynbos (versus populations restricted to limestone fynbos). 

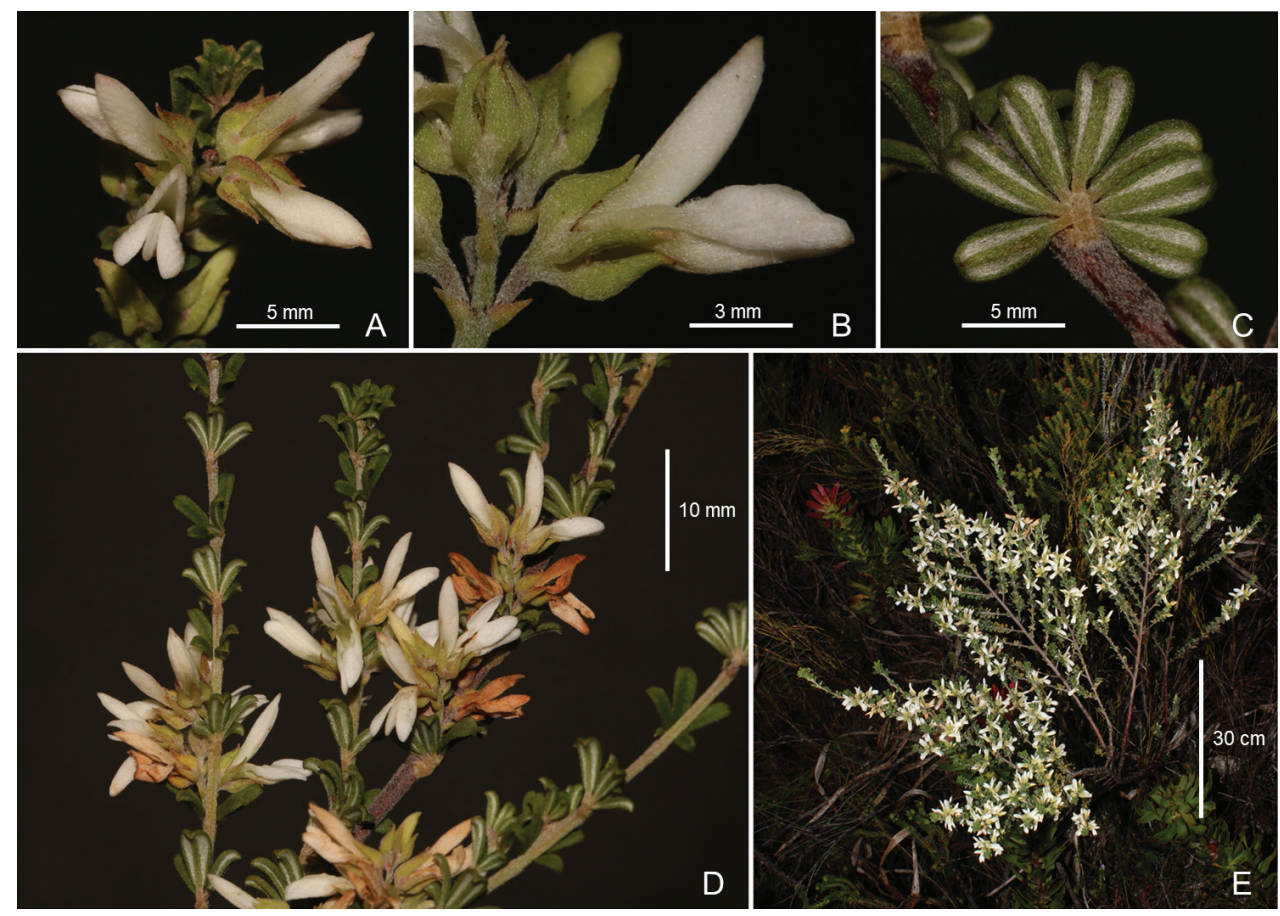

Figure I. Indigofera wenholdiae du Preez \& Schrire A single inflorescence B flower lateral view C leaf abaxial view $\mathbf{D}$ multiple inflorescences on branches $\mathbf{E}$ whole plant. Photographs by Brian du Preez. Voucher B. du Preez 836 (BOL).

Type. South Africa, Western Cape Province, track to Beacon Peak in Grootbos Nature Reserve, Gansbaai District, elevation 257 m, 34³1'32.84"S, 19³0'19.08"E, 7 May 2020, flowering, B. du Preez 836 (Holotype: BOL!; Isotypes: K!, NBG!, PRE!).

Description. Erect perennial shrub $0.4-0.8 \mathrm{~m}$ tall, robust, sparsely branching, divaricate; obligate reseeder. Branches up to $10 \mathrm{~mm}$ thick, terete to ribbed on fresh growth, densely strigose with sessile whitish biramous hairs, glabrescent later, reddishbrown, woody. Stipules $0.8-1.2 \mathrm{~mm}$ long, $\pm 1 \mathrm{~mm}$ wide at base, broadly triangular, asymmetric, navicular-cucullate, attenuate, apex aristate, adpressed to branch, adnate to base of petiole, densely strigose, \pm soft-textured and thickened, pale green, pearl bodies present along margin. Leaves alternate, digitately 5-7 foliolate, petiole $\pm 1 \mathrm{~mm}$ long, sub-terete, flattened adaxially; rachis $\pm 0.5 \mathrm{~mm}$ long, terete, stipels absent; petiolules \pm $0.5 \mathrm{~mm}$ long; terminal leaflet $4-6 \mathrm{~mm} \times 1.5-2.5 \mathrm{~mm}$, narrowly oblanceolate, apex apiculate, hooked, base cuneate, upper surface sparsely strigose, bright green, paler below; lower surface densely strigose; mid-vein sunken adaxially, prominent abaxially; margins not thickened, strongly revolute; lateral leaflets similar, opposite. Racemes axillary, up to $7 \mathrm{~mm}$ long, erect, parallel with branch, roughly equalling the leaf length, including a peduncle 2-3 mm long, ribbed, soft-textured; \pm 4-5 flowered; bracts $\pm 1.5 \mathrm{~mm}$ long, lanceolate, cucullate, apex apiculate, adpressed to petiole, persistent until after flowering, pearl bodies present along margin. Bracteoles absent. Pedicels $1-1.5 \mathrm{~mm}$ long. 


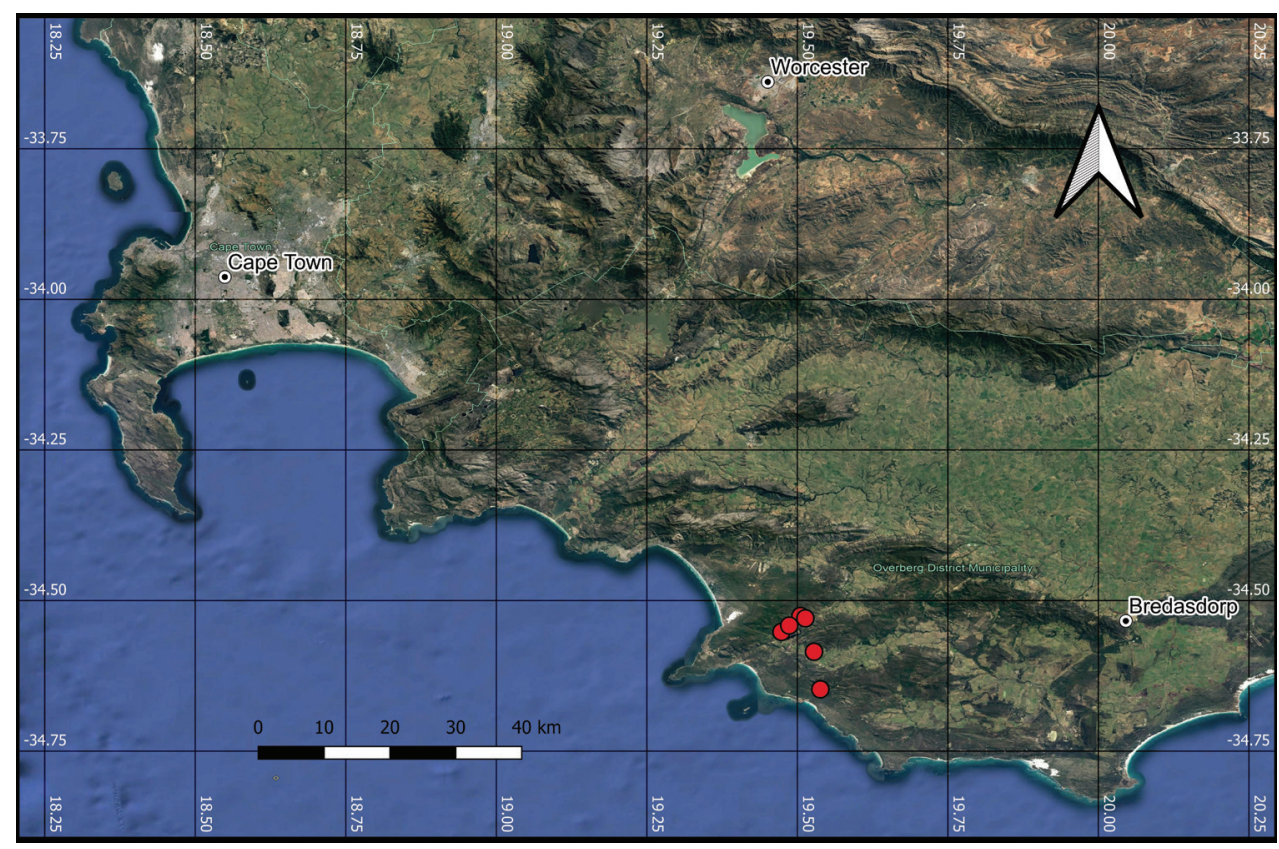

Figure 2. Distribution map of Indigofera wenholdiae.

Flowers 8-9 mm long, unscented. Corolla creamy-white, petals persistent after anthesis. Calyx 3.5-4.2 mm long, pale green, lobes lanceolate, distinctly navicular-cucullate, 2.5-3 mm long, \pm three times tube length, moderately strigose, pearl bodies present along margin. Standard petal $8.7-9.3 \mathrm{~mm} \times 3.3-3.7 \mathrm{~mm}$, broadly oblong, tapering gradually to a short claw at the base; blade concave, nectar guide plain white; apex acuteobtuse; back of standard strigose, no visible colouration patterns. Wing petals $7.5-8 \times$ $1.5-2 \mathrm{~mm}$, shortly clawed at base, unguiculate portion \pm half total petal length, blade asymmetrically navicular, apex rounded; blade moderately strigose. Keel petals $7.5-8$ $\times 1.8-2.3 \mathrm{~mm}$, valvately connate distally, lateral spurs up to $1 \mathrm{~mm}$ long, blade asymmetrically lanceolate, dorsal margin curving slightly downwards to an acute-obtuse apex, densely strigose; claws 2.5-3 mm long. Stamens 5-5.5 mm long, exceeding calyx by $1.5-$ $2 \mathrm{~mm}$, staminal tube pale creamy-green; hair clusters present below anthers. Gynoecium 4-4.5 mm long, strigillose on distal half; style $\pm 2 \mathrm{~mm}$ long, erect to $\pm 1 \mathrm{~mm}$ high distally; stigma capitate. Fruit 13-16 × 2-2.2 mm, oblong, woody, reddish-brown, densely strigillose, 4-5 seeded, dehiscent, ripe fruit not seen. Seeds not seen.

Distribution, habitat and ecology. Indigofera wenholdiae is restricted to a few sandstone hills from the Grootbos Nature Reserve to Pearly Beach on the Agulhas Plain of the Western Cape Province (Figure 2). The species is occasional in Overberg Sandstone Fynbos (FFs12, Mucina and Rutherford 2006), favouring south-facing slopes and hilltops.

Phenology. Flowering takes place from April to July.

Etymology. The specific epithet "wenholdiae" is assigned in honour of Mrs Hannerie Wenhold who has funded large-scale conservation efforts in this area, including 
the funding of the botanist post at Grootbos Nature Reserve of Miss Rebecca Dames who brought this species to our attention in April 2020.

Conservation status. Indigofera wenholdiae is a range-restricted species, with an EOO of $30 \mathrm{~km}^{2}$ and $\mathrm{AOO}$ of $24 \mathrm{~km}^{2}$. A total of six subpopulations across four locations have been discovered, with the number of mature individuals estimated to be less than 10 000. Most subpopulations occur within protected areas or on farms earmarked for conservation. Alien vegetation is prominent in the region, although only one location is currently threatened by invasive species, while alien eradication projects at other locations have largely controlled or eradicated invasive species. The Red List category VU D2 is thus recommended, based on the IUCN Categories and Criteria (IUCN 2012).

Related species. Indigofera wenholdiae is part of Section Brachypodae, a large group ( \pm 30 species) of Indigofera species almost exclusively found in Fynbos vegetation and characterised by having five or more foliolate leaves with short petioles. The $I$. brachystachya group resolves within this section and includes $I$. brachystachya, I. hamulosa and several putative undescribed taxa related to the former. All of these species are characterised by a corolla morphology unique in the genus, with elongate and concave standard petals and, in general, robust rather than delicate petals. All species in this group are coastally distributed and most often occur on limestone substrate. Apart from the distinguishing features noted above, I. wenholdiae is an erect to less than $1 \mathrm{~m}$ tall, divaricately branching shrub with deep green leaves and white flowers, in contrast with the bushier growth of I. brachystachya, with its typically dull grey leaves and pale pink flowers.

Additional specimens examined. Grootbos Nature Reserve, (3419DA), 12 September 2020, B. du Preez 879 (BOL, NBG).

\section{Acknowledgements}

The permit for the collection of herbarium specimens was obtained from the Western Cape Nature Conservation Board (Permit: AAA 008-00222-0028). We wish to thank Miss Rebecca Dames for bringing this species to our attention and who, along with Mr Sean Privett, searched for and located further populations in the area. We wish to also thank Mr Michael Lutzeyer for allowing us access to Grootbos Nature Reserve to study this species. Running costs for research, including fieldwork, were covered by an NRF - FBIP grant awarded to Prof. A.M. Muasya (FBIP180529337017) and personal bursaries awarded by the NRF - FBIP (FBIP 128327) and the Science Faculty PhD Fellowship from the University of Cape Town.

\section{References}

Bello A, Stirton CH, Chimphango SBM, Muasya AM (2017) Taxonomic revision of African Psoralea pinnata species complex (Psoraleeae, Leguminosae). South African Journal of Botany 112: 128-179. https://doi.org/10.1016/j.sajb.2017.05.003 
Cowling RM, Holmes PM (1992) Endemism and speciation in a lowland flora from the Cape Floristic Region. Biological Journal of the Linnean Society. Linnean Society of London 47(4): 367-383. https://doi.org/10.1111/j.1095-8312.1992.tb00675.x

Curtis OE, Stirton CH, Muasya AM (2013) A conservation and floristic assessment of poorly known species rich quartz-silcrete outcrops within Rûens Shale Renosterveld (Overberg, Western Cape), with taxonomic descriptions of five new species. South African Journal of Botany 87: 99-111. https://doi.org/10.1016/j.sajb.2013.03.017

Dahlgren R (1988) Aspalathus (3,6). In: Leistner OA (Ed.) Flora of Southern Africa, 16, Botanical Research Institute, Pretoria.

Du Preez B, Dreyer LL, Stirton CH, Muasya AM (2021) A monograph of the genus Polhillia (Genisteae: Fabaceae). South African Journal of Botany 138: 156-183. https://doi. org/10.1016/j.sajb.2020.12.022

IUCN (2012) IUCN Red List Categories and Criteria, Second ed. IUCN, Gland, Switzerland and Cambridge, UK.

Manning J, Goldblatt P [Eds] (2012) Plants of the Greater Cape Floristic Region. 1: the core Cape flora. South African National Biodiversity Institute, Pretoria, 853 pp.

Moteetee AN, Boatwright JS, Jaca TP (2014) A review of Rhynchosia Section Polytropia (Phaseoleae, Fabaceae) and a new species from the Western Cape Province, South Africa. Systematic Botany 39(4): 1127-1131. https://doi.org/10.1600/036364414X683859

Mucina L, Rutherford MC [Eds] (2006) The vegetation of South Africa, Lesotho and Swaziland. Strelitzia 19. South African National Biodiversity Institute, Pretoria, 801 pp.

Schrire BD, Lavin M, Barker NP, Forest F (2009) Phylogeny of the tribe Indigofereae (Leguminosae-Papilionoideae): Geographically structured more in succulent-rich and temperate settings than in grass-rich environments. American Journal of Botany 96(4): 816-852. https://doi.org/10.3732/ajb.0800185

Stirton CH, Muasya AM (2016) Seven new species and notes on the genus Aspalathus (Crotalarieae, Fabaceae). South African Journal of Botany 104: 35-46. https://doi.org/10.1016/j. sajb.2015.10.007

Stirton CH, Muasya AM (2017) Ten new species and a new record for the genus Otholobium (Psoraleeae, Leguminosae) from South Africa. Kew Bulletin 72(50): 1-27. https://doi. org/10.1007/S12225-017-9722-5

Thwaites RN, Cowling RM (1988) Soil-vegetation relationships on the Agulhas Plain, South Africa. Catena 15(3-4): 333-345. https://doi.org/10.1016/03418162(88)90055-0 